\title{
Influence of a probiotic on broiler performance
}

\section{Letícia Cardoso Bitterncourt ${ }^{1}$, Claudia Cassimira da Silva ${ }^{2}$, Paula Duarte Silva Rangel Garcia ${ }^{1}$, Daniella Carolina Zanardo Donato ${ }^{1}$, Ricardo de Albuquerque ${ }^{1}$, Lúcio Francelino Araújo ${ }^{2}$}

\footnotetext{
${ }^{1}$ Faculdade de Medicina Veterinária e Zootecnia, Departamento de Nutrição e Produção Animal VNP/USP, 13635-900 - Pirassununga, SP - Brazil.

${ }^{2}$ Faculdade de Zootecnia e Engenharia de Alimentos - FZEA/USP, CEP: 13635-900 - Pirassununga, SP - Brazil.
}

ABSTRACT - The objective of the present study was to evaluate the influence of a probiotic product (composition: Lactobacillus acidophillus $\left(3.5 \times 10^{11} \mathrm{CFU}\right)$, Streptcoccus faecium $\left(3.5 \times 10^{11} \mathrm{CFU}\right)$ and Bifidobacterium bifidum $\left(3.5 \times 10^{11} \mathrm{CFU}\right)$ ) on broiler performance. A total of 1200 one-day-old broilers were reared until 42 days of age, and distributed in a completely randomized experimental design with 3 treatments (antibiotic, probiotic and control) with 10 replicates of 40 birds each. Weight gain, feed intake, feed conversion ratio and mortality were evaluated. Concerning weight gain, in the periods of 0-7 and 0-14 days of age, the group fed the antibiotic product presented higher values as compared with the other treatments. However, in the periods of 0-21, 0-28 and 0-35 days of age, birds fed the antibiotic presented higher weight gain only in relation to the control group. Feed intake differences were detected only in the initial period of 0-7 days of age, with the group fed the antibiotic product presenting higher feed intake as compared with that fed the probiotic product, although these groups were not different from the control group. No statistical difference was detected in feed conversion ratio among treatments in any of the evaluated age intervals. Mortality was different only in the period of 0-14 days of age, which was higher in the control group as compared with that of the birds fed the probiotic product, but it was not different from the group receiving the antibiotic. Treatment with probiotic product containing Lactobacillus acidophillus, Streptococcus faecium and Bifidobacterium bifidum does not affect broiler performance.

Key Words: additives, antibiotics, growth promoter, nutrition

\section{Introduction}

There is an increasing demand for quality in animal products, as well as concerns about the effects of these products on human health. Therefore, animal production systems will have to focus not only on obtaining high production, but also on their impact on the environment as well as on human and animal health (Ferket, 2003).

It has been shown by several scientific studies that antibiotics added to animal feeds as growth promoters allow better live performance (Dibner \& Richards, 2005 ); however, the growing concern with the possible relation between in-feed antibiotics and bacterial resistance in livestock and humans has driven the adoption of new measures to control those compounds (Ferket, 2003; Fuller, 1989; Jin, 1997), despite the lack of evidences (Jones \& Ricket, 2005).

In this sense, the authorities of several regions of the world are restricting the use of antibiotics in livestock and establishing routine surveillance and monitoring programs, and suggest that antimicrobials belonging to the same class as those used for humans be banned, except if risk analyses are performed (WHO, 2000).
This situation has driven much research on the search for alternatives that are able to maintain high productivity and to be economically feasible, as well as not being harmful to human and animal health, thereby complying with the requirements of consumers and foreign markets. Among these alternatives, the use of probiotics in animal feeds stands out. These products do not leave residues in animal products and promote animal performance and health (Ferreira et al., 2002; Fuller, 1989; Jin, 1997; Patterson \& Burkholder, 2003; Zulkifli et al., 2000), because they improve diet digestibility (Apata, 2008 ), resulting in better nutrient utilization and consequently, higher productivity (Kabir et al., 2004, Mountzouris et al., 2007; 2010).

The objective of the present study was to evaluate the performance of broilers fed a probiotic product in the feed from 1 to 42 days of age, using the parameters weight gain, feed intake, feed conversion ratio and mortality.

\section{Material and Methods}

The experiment was carried out in the experimental poultry house of the Departamento de Nutrição e Produção Animal da Faculdade de Medicina Veterinária e Zootecnia 
Universidade de São Paulo, Pirassununga campus. The masonry poultry house was divided into 30 floor pens, measuring $4.25 \mathrm{~m}^{2}$ each. The trial was carried out between March 24 and May 04, 2005.

Conventional house management and equipment were used for conventional masonry broiler houses, duly adapted for an experimental house. The house was opensided and manual curtain management was applied. The house did not have air-conditioning equipment.

Birds were weighed on day 1 and housed in the experimental pens. Average, maximum and minimum temperatures were daily recorded using dry-bulb thermometers placed at different locations in the house. During the experimental period, maximum and minimum temperatures recorded were $28^{\circ} \mathrm{C}$ and $20^{\circ} \mathrm{C}$, respectively.

In this trial, 1200 one-day-old AgRoss 308 male chicks were reared until 42 days of age. A completely randomized experimental design was applied, with three treatments of 10 replicates each. Birds were distributed in 30 experimental units of 40 birds each.

The experimental diets were formulated according to the nutritional levels recommended by Rostagno et al. (2005) for broilers. The first treatment consisted of the addition of an antibiotic growth promoter (avilamycin) to the basal diet, and in the second treatment, a probiotic product was added to the basal diet, whereas in the third treatment, no supplementation was employed (control).
The different treatments were established by replacing the tested product (antibiotic or probiotic) with its equivalent weight in inert material (sand). Isoprotein and iso-energy diets, based on corn and soybean meal were formulated (Table 1).

Birds were vaccinated against coccidiosis in the first week of life, using a live attenuated vaccine in the drinking water according to the recomendations of the manufacturer.

The probiotic product included Lactobacillus acidophillus (3.5 × $\left.10^{11} \mathrm{CFU}\right)$, Streptococcus faecium $\left(3.5 \times 10^{11} \mathrm{CFU}\right)$ and Bifidobacterium bifidum $\left(3.5 \times 10^{11}\right.$ CFU), and was added at a dose of $2 \mathrm{~kg} / \mathrm{T}$ feed during the entire rearing period. The tradename of the product is DBA $^{\circledR}$ and it is produced by the company IMEVE.

The following performance parameters were determined at the ages of 7, 14, 21, 28, 35 and 42 days: average weight gain, feed intake, feed conversion ratio (g feed/g weight gain) and mortality.

Results were analyzed using the software Statistical Analysis System (SAS, 1985). Residue normality was first analyzed using the test of Shapiro-Wilk (PROC UNIVARIATE) and variances were compared by the test of Hartley (Ott, 1983). Data were submitted to analysis of variance, and means were compared by the test of Tukey. Analysis of variance was performed using the General Linear Model (PROC GLM of SAS).

Table 1 - Ingredient composition and calculated nutritional composition of experimental diets

\begin{tabular}{lccc}
\hline Ingredients & Starter diet (\%) & Frower diet (\%) & Finisher diet (\%) \\
\hline Corn & 52.26 & 57.11 & 63.70 \\
Soybean meal & 40.13 & 34.00 & 28.00 \\
Soybean oil & 3.52 & 0.90 & 4.5 \\
Salt & 0.35 & 1.60 & 0.35 \\
Limestone & 1.24 & 1.14 & 1.60 \\
Dicalcium phosphate & 1.60 & 0.21 & 0.95 \\
Methionine & 0.24 & 0.30 & 0.18 \\
Vit-Min supplement ${ }^{1}$ & 0.30 & 0.01 & 0.30 \\
Antibiotic & 0.01 & 0.20 & 0.01 \\
Probiotic & 0.20 & 0.18 & 0.20 \\
Inert material & 0.15 & 100 & 0.21 \\
Total & 100 & 3100 & 100 \\
Calculated analysis & & 20.0 & 3150 \\
Metabolizable energy (kcal/kg) & 2950 & 0.32 & 18.0 \\
Protein (\%) & 22.5 & 0.65 & 0.30 \\
Methionine (\%) & 0.35 & 0.95 & 0.60 \\
Methionine cystine (\%) & 0.71 & 0.35 & 0.90 \\
Calcium (\%) & 0.95 & 0.30 & \\
Available phosphorus (\%) & 0.45 & & \\
\end{tabular}




\section{Results and Discussion}

Weight gain, in the periods of $0-7$ and 0 - 14 days of age, was higher in the group fed the antibiotic as compared with birds fed the probiotic product and the control group $(\mathrm{P}<0.05)$, which were not different (Table 2).

In the periods of 0-21, 0-28 and 0-35 days of age, birds fed the antibiotic again presented higher weight gain values, but only as compared with the control group $(\mathrm{P}<0.05)$ and the group fed the probiotic product was not statistically different from the others. In the study of Ramarao et al. (2004) it was also not possible to observe any influence of probiotics on broiler weight gain, as opposed to Kabir et al. (2004), who obtained higher weight gain in broilers fed a probiotic product containing Lactobacillus plantarum, Lactobacillus bulgaricus, Lactobacillus acidophilus, Lactobacillus rhamnosus, Bifidobacterium bifidum, Streptococcus thermophilus, Enterococcus faecium, Aspergillus oryzae and Candida pintolopessi, in relation to the control birds in all rearing periods analyzed (2, 4, 5 and
6 weeks of age). Silva et al. (2011) used the same probiotic product at the same concentrations as in the present study (Lactobacillus acidophillus $\left(3.5 \times 10^{11} \mathrm{CFU}\right)$, Streptococcus faecium $\left(3.5 \times 10^{11} \mathrm{CFU}\right)$ and Bifidobacterium bifidum $\left(3.5 \times 10^{11} \mathrm{CFU}\right)$, but found that, in the period of 0 -21 days, the weight gain of broilers fed the probiotic was higher relative to the group treated with an antibiotic (flavomycin 10\% - 4 ppm and halquinol $60 \%-15 \mathrm{ppm}$ ) and prebiotic (inulin derived from chicory extract) and similar to those fed with a symbiotic product (probiotic + prebiotic).

Differently from the present study, Zulkifli et al. (2000) used a probiotic product containing Lactobaccillus spp and obtained similar weight gain for probiotic- and antibiotic- fed broilers, whose values were higher as compared with the control group during the period of 0-21 days of age. Moreover, during the entire rearing period (0-42 days of age), those authors found that birds fed the probiotic product presented higher weight gain as compared with the other broilers. Boratto et al. (2004), similarly to

Table 2 - Performance of broilers of different ages submitted to the experimental treatments

\begin{tabular}{|c|c|c|c|c|c|}
\hline \multirow[t]{2}{*}{ Parameters } & \multicolumn{3}{|c|}{ Treatments } & \multirow[b]{2}{*}{$\mathrm{P}$} & \multirow[b]{2}{*}{$\mathrm{CV} \%$} \\
\hline & Antibiotic & Probiotic & Control & & \\
\hline \multicolumn{6}{|l|}{$0-7$ days } \\
\hline FI (g) & $101.4 \mathrm{a}$ & $97.7 \mathrm{~b}$ & $99.0 \mathrm{ab}$ & 0.0377 & 3.4 \\
\hline FCR (g/g) & 0.87 & 0.88 & 0.90 & 0.1155 & 3.8 \\
\hline Mort (\%) & 0.25 & 0.00 & 1.00 & 0.1294 & 276.7 \\
\hline FI (g) & 457.7 & 468.6 & 475.9 & 0.5572 & 3.5 \\
\hline FCR (g/g) & 1.29 & 1.30 & 1.34 & 0.0932 & 3.4 \\
\hline Mort (\%) & $1.00 \mathrm{ab}$ & $0.25 b$ & $1.75 \mathrm{a}$ & 0.0529 & 140.8 \\
\hline \multicolumn{6}{|l|}{$0-21$ days } \\
\hline WG (g) & $730.0 \mathrm{a}$ & 716.6ab & 699.0b & 0.0580 & 4.1 \\
\hline WG (g) & $1306.6 \mathrm{a}$ & $1276.2 \mathrm{ab}$ & $1255.8 b$ & 0.0133 & 3.2 \\
\hline FI (g) & 2102.0 & 2090.0 & 2085.9 & 0.8202 & 3.8 \\
\hline FCR (g/g) & 1.61 & 1.64 & 1.66 & 0.1403 & 3.7 \\
\hline Mort (\%) & 7.75 & 7.00 & 8.25 & 0.6605 & 39.2 \\
\hline \multicolumn{6}{|l|}{0 - 35 days } \\
\hline WG (g) & $2018.0 \mathrm{a}$ & $1974.0 \mathrm{ab}$ & $1962.9 b$ & 0.0317 & 2.6 \\
\hline FI (g) & 3373.9 & 3358.7 & 3345.0 & 0.7177 & 2.3 \\
\hline FCR (g/g) & 1.67 & 1.70 & 1.71 & 0.2920 & 2.9 \\
\hline Mort (\%) & 7.75 & 7.25 & 8.25 & 0.7649 & 38.2 \\
\hline \multicolumn{6}{|l|}{$0-42$ days } \\
\hline WG (g) & 2635.5 & 2624.3 & 2585.7 & 0.1839 & 2.4 \\
\hline
\end{tabular}

Means followed by different letters in the same row are different by the test of Tukey $(\mathrm{P}<0.05)$. CV = coefficient of variation. $\mathrm{WG}=\mathrm{weight}$ gain; FI = feed intake; FCR = feed conversion ratio; Mort $=$ mortality. 
Zulkifli et al. (2000), observed higher weight gain in the group treated with a probiotic (Lactobacilus acidophillus, Enterococcus faecium and Saccharomyces cerevisiae) relative to the control group, but no difference from the group fed antibiotics (virginiamycin and nitrovin) in the starter phase; however, weight differences were not observed during the subsequent periods.

Significant differences in feed intake among treatments were observed only in the period of 0-7 days of age, with the group fed the antibiotic presenting higher values as compared with the probiotic group $(\mathrm{P}<0.05)$, but the average feed intake of these two groups was not significantly different from the control group. No statistical differences between treatments were observed during the other periods. The lack of influence of feed additives was also observed by Maiorka et al. (2001), when testing antibiotic (Olaquindox ${ }^{\circledR}$ and Nitrovin), prebiotic (Saccharomyces cerevisiae), probiotic (Bacillus subtilis) products and an association of prebiotic and probiotic (symbiotic), as well as by Pelicano et al. (2004a), who evaluated probiotics (1 - Bacillus subtilis; 2 - Lactobacillus acidophilus, Lactobacillus casei, Streptococcus lactis, Streptococcus faecium, Bifidobacterium bifidum, Aspergillus oryzae) and prebiotics and did not observe any difference in feed intake with the dietary inclusion of these products. On the other hand, Silva et al. (2011) verified lower feed intake in the period of 0-21 days when the dietary inclusion of antibiotic was compared with a probiotic and other treatments.

However, other experiments have showed the influence of probiotics and antibiotics on the feed intake of broilers. Corrêa et al. (2003) tested different probiotics in broiler diets (Bacillus subtllis, Bacillus toyoi, Lactobacillus acidophilus, Lactobacillus casei, Streptococcus salivarium, Streptococcus faecium and Saccharomyces cerevisiae) and an antibiotic (zinc bacitracin) and observed lower feed intake in the group fed one of the probiotics relative to the control group in the period of 0 - 21 days of age, which was also verified by Zulkifli et al. (2000). Boratto et al. (2004), however, in the same period, found higher feed intake in broilers fed probiotics, in relation to the control group and the group fed an antibiotic.

Mortality differences were observed only in the period of 0-14 days of age, with higher values in the control group as compared with the probiotic group $(\mathrm{P}<0.05)$, whereas the group fed the antibiotic was not different in relation to the others. Considering the other experimental periods, no influence of additives on mortality was detected, contrarily to the findings of Pelicano et al. (2004a), who, in a study on the use of probiotics and prebiotics in broilers, observed higher livability when these additives were added to the diet.

The parameter feed conversion ratio was not statistically different between treatments in none of the studied intervals, as also observed in the experiment of Loddi et al. (2000), who worked with a probiotic product containing Enterococcus faecium $\left(1 \times 10^{10} \mathrm{CFU} / g\right.$ product), and Rocha et al. (2010), who used one probiotic containing Bacillus subtillis ( $\left.10^{9} \mathrm{CFU}\right)$ and another containing Lactobacillus plantarum, Lactobacillus bulgaricus, Lactobacillus acidophilus, Lactobacillus rhamnosus, Bifidobacterium bifidum, Streptococcus thermophilus, and Enterococcus faecium. Other authors, however, obtained better feed conversion ratio in broilers fed probiotics in the periods of 0-21 days (Corrêa et al, 2003; Maiorka et al., 2001; Pelicano et al., 2004a; Zulkifli et al., 2000) and 0-40 days (Boratto et al., 2004; Maiorka et al., 2001).

Considering the total rearing period, from one to 42 days of age, none of the treatments statistically influenced the evaluated parameters, which was also observed by Lima et al. (2003), who worked with Bacillus subtilis $\left(1 \times 10^{10}\right.$ CFU/g product), Pelicano et al. (2004b), who used Bacillus subtilis, Bacillus licheniformis, Lactobacillus reuteri and Lactobacillus johnsonii, Appelt et al. (2010), who tested different Bacillus subtilis feed inclusion levels, Boratto et al. (2004), Junqueira et al. (2006) and Silva et al, (2011). On the other hand, Santos et al. (2004), including antibiotics and probiotics in broiler feeds, despite not detecting differences in body weight, weight gain or feed intake in broilers from one to 42 days of age, showed that the antibiotic product promoted better feed conversion ratio.

The inclusion of probiotics in broiler diets produced the best results during the initial period, between 0-21 days of age, but these differences were neither maintained for the period of 0 -days nor for the entire rearing period in the study of Pelicano et al. (2004a).

Rearing conditions may directly influence the efficiency of growth promoter additives (Boratto, 2004; Takahashi et al., 1997). Adequate management practices, such as those applied in the present experiment, may not show any significant effect of these additives on broiler performance.

The presence of health challenges and stress in the rearing environment, as well as the number and strains of viable microorganisms in the probiotic product determine the efficacy of these additives (Lima et al., 2003), and therefore, it is difficult to compare the results of different studies (Boratto, 2004; Loddi et al., 2000). Moreover, there is a wide range of probiotic products, administration routes, and experimental conditions reported in the literature 
(Boratto, 2004). Santos (2010) mentions that the efficacy or inefficacy of a probiotic product may be related to its microbial composition and viability, administration method and frequency, bird age, hygiene of the facilities, feed composition (cereals and their synergism or antagonism relative to the microbes in the product), as well as environmental stress factors.

\section{Conclusions}

The addition of the probiotic product containing Lactobacillus acidophillus, Streptococcus faecium and Bifidobacterium bifidum, to broiler diets does not influence the performance of broilers.

\section{References}

APPELT, M.D.; NUNES, R.V.; POZZA, P.C. et al. Níveis de probiótico em rações de origem animal e vegetal para frangos de corte. Revista Brasileira de Zootecnia, v.39, n.4, p.765-771, 2010.

APATA, D.F. Growth performance, nutrient digestibility and immune response of broiler chicks fed diets supplemented with a culture of Lactobacillus bulgaricus. Journal of Science Food Agriculture, v.88, p.1253-1258, 2008.

BORATTO, A.J. Uso de antibiótico, de probiótico e de homeopatia, inoculados ou não com Escherichia coli, para frangos de corte criados em conforto. Revista Brasileira de Zootecnia, v.33, n.6, p.1477-1485, 2004.

CORRÊA, G.S.S. Efeitos de antibiótico e probióticos sobre desempenho e rendimento de carcaça de frangos de corte. Arquivo Brasileiro de Medicina Veterinária e Zootecnia, v.55, n.4, 2003.

DIBNER, J.J.; RICHARDS, J.D. Antibiotics growth promoters in agriculture: history and mode of action. Poultry Science, v.84, p.634-643, 2005.

FERKET, P.R. Manutenção da saúde intestinal em um mundo sem antibióticos. In: RONDA LATINO AMERICANA DA ALLTECH, 13., 2003, Campinas. Anais... Campinas: Alltech, 2003. p.26-39.

FERREIRA, A.J.P.; PIZARRO, L.D.C.R.; LEME, I.L. Probióticos e prebióticos. In: SPINOSA, H.S.; GORNIAK, S.L.; BERNARDI, M.M. (Eds.) Farmacologia aplicada à medicina veterinária. 3.ed. Rio de Janeiro: Guanabara Koogan, 2002. p.574-578.

FULLER, R. Probiotic in man and animals. Journal of Applied Bacteriology, v.66, p.365-378, 1989.

JIN, L.Z. Probiotic in poultry: modes of action. World's Poultry Science Journal, v.53, p.351-368, 1997.

JONES, E.T.; RICKET, S.C. Simposium: antibiotics in animal feeds: are there viable alternatives? - Introduction. Poultry Science, v.84, p.633, 2005.

JUNQUEIRA, O.M.; TANAKA, A.H.; DALANEZI, J.A. et al. Desempenho, rendimento de carcaça e gordura abdominal de frangos de corte submetidos a diferentes promotores de crescimento. Revista Brasileira de Ciência Avícola (Premio Lamas 2006 - APINCO), supl. 8, p.59, 2006.

KABIR, S.M.L.; RAHMAN, M.M.; RAHMAN, M.B. et al. The dynamics of probiotics on growth performance and immune response in broilers. International Journal of Poultry Science, v.3, n.5, p.361-364, 2004.

LIMA, A.C.F. Efeito do uso de probiótico sobre o desempenho e atividade de enzimas digestivas de frangos de corte. Revista Brasileira de Zootecnia, v.32, n.1, p.200-2007, 2003.
LODDI, M.M. Uso de probiótico e antibiótico sobre o desempenho, o rendimento e a qualidade de carcaça de frangos de corte. Revista Brasileira de Zootecnia, v.29, n.4, p.1124-1131, 2000.

MAIORKA, A.; SANTIN, E.; SUGETA, S.M. et al. Utilização de prébióticos, probióticos e simbióticos em dietas para frangos. Revista Brasileira de Ciência Avicola, v.3, n.1, p.75-82, 2001.

MOUNTZOURIS, K.C.; TSIRTISIKOS, P.; KALAMARA, E. et al. Evaluation of the efficacy of a probiotic containing Lactobacillus, Bifidobacterium, Enterococcus and Pediococcus strains in promotion broiler performance and modulation cecal microflora composition and metabolic activies. Poultry Science, v.86, p.309-317, 2007.

MOUNTZOURIS, K.C.; TSIRTISIKOS, P.; PALAMIDI, I. et al. Effects of probiotic inclusion levels in broiler nutrition on growth performance, nutrient digestibility, plasma immunoglobunis, and cecal microflora composition. Poultry Science, v.89, p.58-67, 2010.

OTT, R.L. An introduction to statistical methods and data analysis. Wadsworth: Duxbury Press, 1983. 354p.

PATTERSON, J.A.; BURKHOLDER, K.M. Application of prebiotics and probiotics in poultry production. Poultry Science, v.82, p.627-631, 2003.

PELICANO, E.R.L.; SOUZA, R.A.; SOUZA, H.B.A. et al. Productive traits of broiler chickens fed diets containing differents growth promoters. Brazilian Journal of Poultry Science, v.6, n.3, p.177-182, 2004a.

PELICANO, E.R.L.; SOUZA, R.A.; SOUZA, H.B.A. et al. Performance of broilers fed diets containing natural growth promoters. Brazilian Journal of Poultry Science, v.6, n.4, p.231-236, 2004b.

RAMARAO, S.V.; REDDY, M.R.; RAJU, M.V.L.N. et al. Growth, nutrient utilization competence in broiler chicken fed probiotic, gut acidifier and antibacterial compounds. Indian Journal of Poultry Science, v.39, n.2, p.125-130, 2004.

ROCHA, A.P.; ABREU, R.D.; COSTA, M.C. et al. Prebióticos, ácidos orgânicos e probióticos em rações para frangos de corte. Revista Brasileira de Saúde e Produção Animal, v.11, n.3, p.793-801, 2010.

ROSTAGNO, H.S.; ALBINO, L.F.; DONZELE, J.L. et al. Composição de alimentos e exigências nutricionais de aves e suínos (Tabela Brasileira). Viçosa, MG: UFV, 2005. $186 \mathrm{p}$.

SANTOS I.I. Efeitos de probiótico, óleos essenciais, e enzimas em parâmetros produtivos e sanitários de frangos de corte. 2010. 207f. Tese (Doutor em Zootecnia) - Universidade Federal do Rio Grande do Sul, Porto Alegre.

SANTOS, I.I.; POLI, A.; PADILHA, M.T.S. Desempenho zootécnico e rendimento de carcaça de frangos de corte suplementados com diferentes probióticos e antimicrobianos. Acta Scientiarum Animal Sciences, v.26, n.1, p.29-33, 2004.

SILVA W.T.M.; NUNES R.V.; POZZA, P.C. et al. Avaliação de inulina e probiótico para frangos de corte. Acta Scientiarum Animal Sciences, v.33, n.1, p.19-24, 2011.

STATISTICAL ANALISYS SYSTEM - SAS. SAS user's guide: statistics. 5.ed., Cary: SAS, 1985. 956p.

TAKAHASHI, K.; AKIBA, Y.; MATSUDA, A. Effect of probiotic on immune responses in broiler chicks under different sanitary conditions or immune activations. Animal Science and Technology, v.68, n,6, p.537-544, 1997.

WORLD HEALTH ORGANIZATION - WHO. Global principles for the containment of antimicrobial resistance in animals intended for food. Document WHO/CDS/CSR/APH/ 2000.4. Geneva, Switzerland, 2000. p.1-23.

ZULKIFLI, I. Growth performance and immune response of two commercial broiler strains fed diets containing Lactobacillus cultures and oxytetracycline under heat stress conditions. British Poultry Science, v.41, p.593-597, 2000. 